\title{
Biological screening of Amaranthus retroflexus L. (Amaranthaceae)
}

\author{
Jamileh Salar Amoli, ${ }^{1}$ Parisa Sadighara, ${ }^{* 1}$ Abbas Barin, ${ }^{2}$ \\ Azam Yazdani, ${ }^{3}$ Saeed Satari ${ }^{4}$ \\ ${ }^{1}$ Department of Toxicology, Faculty of Veterinary, Tehran University, Azadi Street, Tehran, \\ Iran \\ ${ }^{2}$ Department of Clinical Pathology, Faculty of Veterinary, Tehran University, Azadi Street, \\ Tehran, Iran \\ ${ }^{3}$ Department of Poultry, Faculty of Veterinary, Tehran University, Azadi Street, Tehran, \\ Iran
}

\begin{abstract}
RESUMO: Abordagem biológica de Amaranthus retroflexus L. (Amaranthaceae). Ensaios biológicos foram realizados para determinação da toxidade de Amaranthus retroflexus L. (Amaranthaceae) conhecido popularmente como "redroot pigweed". Extratos desta espécie foram testados para avaliar sua bioatividade em Artemia salina e citoxidade em células bovinas de rim. Os valores de $\mathrm{DL}_{50}$ para Artemia salina foram medidos a $1700 \mathrm{ppm}$. As células de rim bovinas foram expostas a várias concentrações dos extratos de plantas (100-0,1 ppm). Após tratamento com 100 e $0,1 \mathrm{ppm}$ por $24 \mathrm{~h}$, a viabilidade celular foi reduzida a cerca de $49 \%$ e $35 \%$, respectivamente, no ensaio de MTT. O estudo confirma que Amaranthus retroflexus apresenta um efeito citotóxico e, mais especificamente, para células renais.
\end{abstract}

Unitermos: Amaranthus retroflexus, Amaranthaceae, Artemia salina, ensaio MTT.

\begin{abstract}
Bioassays are required for the determination of the total toxicity of Amaranthus retroflexus L. (Amaranthaceae) or "redroot pigweed". Therefore, the plant extract has been tested for bioactivity in Artemia salina and cytotoxicity against bovine kidney cells. The $\mathrm{LD}_{50}$ values for Artemia salina were measured at $1700 \mathrm{ppm}$. The bovine kidney cells were exposed to various concentrations of the plant extracts $(100 \mathrm{ppm}-0.1 \mathrm{ppm})$. After treating with 100 and $0.1 \mathrm{ppm}$ for $24 \mathrm{~h}$, the cells viability were reduced by about $49 \%$ and $35 \%$ respectively in MTT viability assay. The study confirmed that Amaranthus retroflexus has a cytotoxic effect and more specific to renal cells.
\end{abstract}

Keywords: Amaranthus retroflexus, Amaranthaceae, brine shrimp lethality assay, MTT assay.

\section{INTRODUCTION}

Plants are unique in their ability to produce an extraordinary array of different secondary metabolites. Many of these metabolites have medicinal or toxic attributes (Barthelson et al., 2006). Form many centuries, the leaves and seeds of Amaranthus species such as A. retroflexus have been sources of food for native people from North and South America to Asia, Africa and Europa (Pacifico et al., 2008). In northern Iran leaves of redroot pigweed are eaten in soups. This plant has not been investigated for toxicity so far. There is a possibility that this plant can be toxic to human. Cases of poisoning have been observed in veterinary reports. The toxic effects due to the use are associated with nephrotoxicity. Ingestion of $A$. retroflexus causes perirenal to toxic nephrosis in the swine and the cattle (Maxie, 2007). Acute renal failure and perirenal oedema has been described in cattle, pigs, horses and sheep associated with the ingestion of $A$. retroflexus (Last et al., 2007). In microscopic lesion; necrosis of proximal and distal tubules in poisoned cattle was observed (Plumlee, 2004). It contains an unknown toxicant that causes renal tubular nephrosis. Histopathological findings in forty seven of poisoned cows were tubular degeneration, necrosis and regeneration with interstitial fibrosis and tubular proteinosis (Torres et al., 1997).

Nephrotoxic insults may result in cellular injury. Various clinical and laboratory approches have been used to evaluate renal toxicity. In vitro toxicology analysis using cell cultures has been developed into an important alternative for early toxicity assessment. In order to determine the effects of plant extracts cell culture system, vertebrate cells cultured in vitro have been grown in monolayer on artificial substrate (Saad et al., 2006). With regard to the 
in vitro renal system, the porcine cell line has been used to assess renal toxicity mechanisms. Rodent primary renal cell lines were also used for investigating nephrotoxicity of anticancer drugs (Li et al., 2006). Moreover, in vitro cytotoxic activity of different extracts or drugs are usually assessed by MTT mitochondrial reduction (Sabino et al., 1999; Shoeb et al., 2007). Therefore, we used bovine renal cells as models for toxicity analysis with MTT assay.

Also, the brine shrimp have been used to detect general toxicity, in teratology screens, ecotoxicology and detection of plant extract toxicity for the past 30 years (Carballo et al., 2002). It has been established as safe, practical and economic method for determination of bioactivity of plant product (Silva et al., 2007; Subhan et al., 2008). This present study was conducted to assess toxicity of leaves by brine shrimp lethality assay and cytotoxicity activity against bovine kidney cells.

\section{MATERIAL AND METHODS}

MTT 3-(4,5-dimethylthiazole-2-il) 2,5dipheniltetrazolium bromide (Merk), isopropanol (Merk), Schleicher \& Schuell Filter (pore size $0.2 \mu \mathrm{m}$ ) were used. Amaranthus retroflexus leaves were collected from northern Iran and identified by Dr. H.R. Alvai 233. Voucher specimen of this plant was deposited in the central herbarium of medicinal plants, Tehran University of Medical Sceiences.

\section{Extraction}

Amaranthus retroflexus leaves were extracted in a soxhlet apparatus with a mixture of $\mathrm{MeOH}$-acetonewater. The extract was evaporated in a rotary evaporator, transferred to vials, and kept at $4^{\circ} \mathrm{C}$.

\section{Brine shrimp lethality assay}

Artemia salina is commonly known as the brine shrimp. Larvae were hatched from cysts (San Francisco Bay brand) at $26{ }^{\circ} \mathrm{C}$ in filtered seawater. A lamp was placed above the tank. After $24 \mathrm{hrs}$, hatched nauplii were used for the assay. Plant extract $(0.5 \mathrm{~mL})$ with different concentration (10, 100 and $1000 \mathrm{ppm})$ was added to $5 \mathrm{~mL}$ of brine solution. The experiment was run in five replicates of each concentration. The number of dead and survivor brine shrimps in each tube was counted after $24 \mathrm{~h}$. To ensure that mortality observed in the bioassay is related to bioactive compounds, dead larvae in each treatment were compared to the dead larvae in the control. The percentage of mortality was calculated as: percentage of survival in the control-percentage of survival in the treatment (Carballo et al., 2002).

\section{MTT assay}

Bovine kidney cells were obtained from Iran's Razi Institute (RBK30). Cells were maintained in Dulbecco's Modified Eagle's Medium (DMEM) at $37{ }^{\circ} \mathrm{C}$ in a humidified atmosphere and $5 \% \mathrm{CO}_{2}$. The cells were seeded in a 96-wel microplate, cells were exposed to various concentrations of the plant extract $(100 \mathrm{ppm}-0.1 \mathrm{ppm})$ in fresh serum-free medium after 48 hours. Plant extraction was filtered through filter before using. Following removal of the plant extracts from each well, cells were washed in phosphate-buffered saline. MTT was added to each well and incubated for a further $3 \mathrm{~h}$. Then, the medium was removed and the cells were incubed with isopropanol to dissolve the formazan crystals. The optical density was measured at $492 \mathrm{~nm}$ with $620 \mathrm{~nm}$ as a reference and cell viability was normalized as a percentage on control.

\section{RESULTS}

The results of the brine shrimp lethality test are presented in Figure 1. The $\mathrm{LC}_{50}$ values were analyzed by regression and found the concentration which needed to die half the nauplii in brine shrimp test. $\mathrm{LD}_{50}$ values for Artemia salina was 1700 ppm.

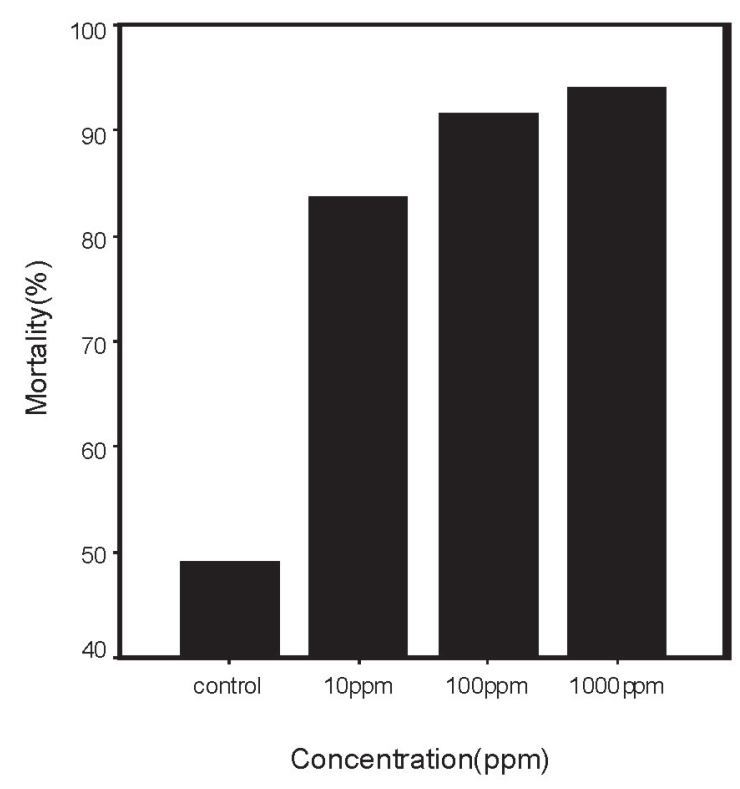

Figure 1. The toxicity of Amaranthus retroflexus on brine shrimp.

After treating with 100 and $0.1 \mathrm{ppm}$ for $24 \mathrm{~h}$, the cells viability reduced to about $49 \%$ and $35 \%$ respectively in MTT viability assay.

\section{DISCUSSION}

Plants have complex mixtures of terpenes, alkaloids, saponins and other chemicals (Saad et al., 
2006). Safety assessment should be tested for medical plants or plants for human nutrition. Therefore, national health authorities are beginning to express concern over the safety and efficacy of these plants. To our knowledge, there are no reports about risk assessment of $A$. retroflexus. In this study we present primary results obtained from $A$. retroflexus, engaged for brine shrimp lethality test and MTT bioassays.

The nephrotoxic principals of $A$. retroflexus have not yet been identified, the plants often contain high levels of nitrate and oxalate but usually neither nitrate nor oxalate poisoning occurs and does not produce perirenal edema (Maxie, 2007). Recently, four new sesquiterpene glucosides were isolated from the methanolic extracts which have a moderate phytotoxic activity down to $10^{-9} \mathrm{M}$ (Fiorentino et al., 2006).

Among different cytotoxicity tests, the radioisotope incorporation and MTT assays are most suitable (Lee et al., 2000). Mitochondria are essential organelles that play an important role in cell metabolism. The MTT assay represents an important method to evaluate mitochondrial damage (Sabino et al., 1999). In this work, we evaluate the MTT reduction activity of renal cell to verify the cytotoxic effects of Amaranthus retroflexus. The loss of viability was clearly evident after $24 \mathrm{~h}$, exposure.

The brine shrimp assay is one of the best and rapid biological and toxicological assays for all the labs (Kanwar, 2007). The extracts are considered inactive when $\mathrm{LC}_{50}$ values greater than $1000 \mathrm{ppm}$ (Alanis-Garza et al., 2007). The evaluation of using Artemia salina indicates general toxicity sometimes, further and specific investigations will be required. Based on the results, extract of Amaranthus retroflexus was not toxic for Artemia salina but data which is taken of basal cytotoxicity, suggest that Amaranthus retroflexus has direct toxicity on renal cells. This suggests that the toxins in Amaranthus retroflexus extracts may be more specific to renal cells.

In conclusion, this report confirms Amaranthus retroflexus only is toxic in renal cell culture. Therefore, the extract of this plant has cytotoxic effects and more specific to renal cells. In spite of the relatively artificial conditions imposed by in vitro studies, compiled data demonstrating that the in vitro uptakes of various organic acids, bases, sugars, amino acids, and inorganic electrolytes were essentially identical to those under in vivo conditions (Lu, 1996). Nevertheless, basal cytotoxicity represents the most fundamental and most common form of cellular toxicity. An important function of cells in vivo is their ability to metabolize chemicals to more or less toxic compounds (Walum, 1998). Some in vivo study such as urinary concentrating ability and kidney weight are the most sensitive and consistent indicators of nephrotoxicity (Lu, 1996). Therefore, other evaluation of nephrotoxicity in vivo condition is also needed.

\section{ACKNOWLEDGMENTS}

We thank Mr.Rahimi for his valuable help.

\section{REFERENCES}

Alanis-Garza BA, Gonzalez-Gonzalez GM, Salazar-Aranda R, Waksman de Torres N, Rivas-Galindo VM 2007. Screening of antifungal activity of plants from the northeast of Mexico. J Ethnopharmacol 114: 468-471.

Barthelson RA, Sundareshan P, Galbraith DW, Woosley RL 2006. Development of a comprehensive detection method for medicinal and toxic plant species. Am J Bot 93: 566574.

Carballo JH, Hernandez-Inda ZL, Perez P, Garcia-Gravalos MD 2002. A comparison between two brine shrimp assays to detect in vitro cytotoxicity in marine natural products. BMC Biotechnol 2: 17.

Fiorentino A, Dellagreca MD, Abrosca B, Golino A, Pacifico S, Izzo A, Monaco P 2006. Unusual sesquiterpene glucosides from Amaranthus retroflexus. Tetrahedron 62: 8952-8958.

Last RD, Hill JH, Theron G 2007. An outbreak of perirenal oedema syndrome in cattle associated with ingestion of pigweed (Amaranthus hybridus L.). J S Afr Vet Assoc. 78: 171-174.

Lee MK, Cheng BWH, Che CT, Hsieh DPH 2000. Cytotoxicity assessment of Ma-huang (Ephedra) under different condition of preparation. Toxicol Sci 56: 424-430.

Li W, Lam M, Choy D, Birkeland A, Sullivan ME, Post JM 2006. Human primary renal cells as a model for toxicity assessment of chemo-therapeutic drugs. Toxicol In Vitro 20: 669-676.

Lu FC 1996. Basic toxicology. 3ed. Taylor \& Francis, p. 200201.

Kanwar AS 2007. Brine shrimp (Artemia salina) a marine animal for simple and rapid biological assays. $J$ Chinese Clin Med 2: 236-240.

Maxie MG 2007. Pathology of domestic animals. 5th ed. Vol 2. Elsevier Saunders, p. 472.

Pacifico S, Abrosca B, Golino A, Mastellone C, Piccolella S, Fiorentino A, Monaco P 2008. Antioxidant evaluation of polyhydroxylated nerolidols from redroot pigweed (Amaranthus retroflexus) leaves. Food Sci Technol-LEB 41: $1665-1671$.

Plumlee KH 2004. Clinical veterinary toxicology. Mosby, INC.

Saad B, Azaizeh H, Abu-Hijleh GH, Said O 2006. Safety of traditional Arab herbal medicine. Evid Based Complement Alternat Med 3: 433-439.

Sabino KCC, Gayer CRM, Vaz LCA, Santos LRL, Felzenszwalb I, Coelho MGP 1999. In vitro and in vivo toxicological study of the Pterodon pubescens seed oil. Toxicol Lett 108: 27-35.

Shoeb M, MacManus SM, Jaspars M, Kong-Thoo-Lin P, Nahar L, Celik S, Sarker SD 2007. Bioactivity of two Turkish endemic Centaurea species, and their major constituents. 
Rev Bras Farmacogn 17: 155-159.

Silva TM, Nascimento RJ, Batista MB, Agra MF, Camara CA 2007. Brine shrimp bioassay of some species of Solanum from Northeastern Brazil. Rev Bras Farmacogn 17: 3538.

Subhan N, Alam MA, Ahmed F, Shahid IJ, Nahar L, Sarker SD 2008. Bioactivity of Excoecaria agallocha. Rev Bras Farmacogn 18: 521-526.

Torres MB, Kommers GD, Dantas AF, de Barros CL 1997. Redroot pigweed (Amaranthus retroflexus) poisoning of cattle in Southern Brazil. Vet Hum Toxicol 39: 94-96.

Walum E 1998. Acute oral toxicity. Environ Health Persp 106: 479-503. 